\title{
First-principles study of the optoelectronic properties and photovoltaic absorber layer efficiency of Cu-based chalcogenides
}

\author{
N. Sarmadian, ${ }^{\text {a) }}$ R. Saniz, B. Partoens, and D. Lamoen \\ EMAT and CMT Groups, Departement Fysica, Universiteit Antwerpen, Groenenborgerlaan 171, \\ B-2020 Antwerpen, Belgium
}

(Received 20 May 2016; accepted 7 August 2016; published online 30 August 2016)

\begin{abstract}
$\mathrm{Cu}$-based chalcogenides are promising materials for thin-film solar cells with more than $20 \%$ measured cell efficiency. Using first-principles calculations based on density functional theory, the optoelectronic properties of a group of $\mathrm{Cu}$-based chalcogenides $\mathrm{Cu}_{2}-\mathrm{II}-\mathrm{IV}-\mathrm{VI}_{4}$ is studied. They are then screened with the aim of identifying potential absorber materials for photovoltaic applications. The spectroscopic limited maximum efficiency (SLME) introduced by Yu and Zunger [Phys. Rev. Lett. 108, 068701 (2012)] is used as a metric for the screening. After constructing the currentvoltage curve, the SLME is calculated from the maximum power output. The role of the nature of the band gap, direct or indirect, and also of the absorptivity of the studied materials on the maximum theoretical power conversion efficiency is studied. Our results show that $\mathrm{Cu}_{2} \mathrm{II}-\mathrm{GeSe}_{4}$ with $\mathrm{II}=\mathrm{Cd}$ and $\mathrm{Hg}$, and $\mathrm{Cu}_{2}-\mathrm{II}-\mathrm{SnS}_{4}$ with $\mathrm{II}=\mathrm{Cd}, \mathrm{Hg}$, and $\mathrm{Zn}$ have a higher theoretical efficiency compared with the materials currently used as absorber layer. Published by AIP Publishing.
\end{abstract}

[http://dx.doi.org/10.1063/1.4961562]

\section{INTRODUCTION}

The potential applications of the multinary chalcogenide semiconductors in optoelectronics give rise to an intense interest in their design and synthesis that dates back to the 1950s. ${ }^{1-4}$ Ternary I-III-VI 2 compounds can be generated from binary II-VI chalcogenides through substituting group II atoms by pairs of group I and III atoms. Because of the increased chemical and structural flexibility in ternary compounds, they exhibit a larger variety of optoelectronic properties compared with binary ones. ${ }^{5}$ For example, $\mathrm{CuGaSe}_{2}$ has a band gap of $1.68 \mathrm{eV}$ which is lower than that of $\mathrm{ZnSe}$ $(2.82 \mathrm{eV}){ }^{6}$ This is one of the characteristics of $\mathrm{CuGaSe}_{2}$ that makes it convenient for application in thin-film solar cells. Further flexibility is obtained by introducing quaternary chalcogenides and this allows to engineer the functional properties to satisfy a certain application, e.g., high-efficiency photovoltaic absorber layers or light emitting diodes.

There are two approaches to substitute the cations in ternary $\mathrm{I}-\mathrm{III}-\mathrm{VI}_{2}$ to design quaternary compounds. One is to replace two III atoms by one II and one IV atom, forming a $\mathrm{I}_{2-}$ II-IV-VI $\mathrm{VI}_{4}$ compound. The other one is to replace one I atom and one III atom by two II atoms, forming $\mathrm{II}_{2}-\mathrm{I}-\mathrm{III}-\mathrm{VI}_{4}$ compounds. Such quaternary chalcogenides with $\mathrm{I}=\{\mathrm{Cu}, \mathrm{Ag}\}$, II $=\{\mathrm{Zn}, \mathrm{Cd}\}, \mathrm{III}=\{\mathrm{Ga}, \mathrm{In}\}, \mathrm{IV}=\{\mathrm{Ge}, \mathrm{Sn}\}$, and VI $=\{\mathrm{S}, \mathrm{Se}$, Te $\}$ have been synthesized by different groups. ${ }^{2,3,7}$ In particular, $\mathrm{Cu}$-based chalcogenides $\mathrm{Cu}_{2}-\mathrm{II}-\mathrm{IV}-\mathrm{VI}_{4}$ can be found at the center of various technological innovations. Among these compounds, $\mathrm{Cu}_{2} \mathrm{ZnSnS}_{4}$ (CZTS) and $\mathrm{Cu}_{2} \mathrm{ZnSnSe}_{4}$ (CZTSe) combine promising characteristics for optoelectronic applications (e.g., direct band gap of $1.0-1.4 \mathrm{eV}$, a high optical absorption coefficient up to $10^{5} \mathrm{~cm}^{-1}$, and a relatively high abundance of the elements ${ }^{4,8,9}$ ). Such characteristics make them the low-cost alternative to the conventional photovoltaic

a)nasrin.sarmadian@uantwerpen.be materials like $\mathrm{Si}, \mathrm{CdTe}$, and $\mathrm{CuIn}_{1-x} \mathrm{Ga}_{x} \mathrm{Se}_{2} .{ }^{8,9}$ While significant attention has been paid to CZTS and CZTSe, ${ }^{1,10,11}$ most of the other compounds in this family remain relatively unexplored. Limited theoretical attention has been paid to these chalcogenides, so their electronic structure and optical properties remain unclear, which limits their usage in semiconductor devices. A deeper knowledge of their optoelectronic properties might bring further improvements in their applications. ${ }^{12}$

On the one hand, extensive measurements have been performed to study the change of the power conversion efficiency of the photovoltaic solar cells with respect to the characteristics of the absorber layers. On the other hand, the conversion efficiency of the solar cells is investigated theoretically, but very few of such studies calculate the efficiency of the solar cells using first-principles methods. Some successful first-principles studies have identified new materials with high conversion efficiency for photovoltaic applications. ${ }^{13-15} \mathrm{Yu}$ and Zunger introduced the "spectroscopic limited maximum efficiency (SLME)" which is a theoretical power efficiency that can be investigated using first-principles calculated quantities. They used the SLME parameter as a selection metric to identify new absorber materials. ${ }^{13}$

The SLME metric is a generalization of the well-known Shockley-Queisser (SQ) criterion for the maximum efficiency of an absorber layer ${ }^{16}$ and through its explicit dependence on the film thickness and absorption spectrum of the compound it is well suited to characterize thin film absorber layers. The thickness of the absorber layers in the existing thin film solar cells (e.g., $\mathrm{Cu}\{\mathrm{In}, \mathrm{Ga}\} \mathrm{Se}_{2}$ ) is few micrometers. ${ }^{17}$ Further decrease in thickness is desirable to reduce cost, processing time, and material usage with only minor loss in performance of the solar cell. Calculating the SLME of a material provides insight about how thin that material can be made with no significant loss in its efficiency.

One of the main goals of the present manuscript is to investigate how the optoelectronic properties of the 
$\mathrm{Cu}_{2}$-II-IV- $\mathrm{VI}_{4}$ compounds change by modifying the material composition. Moreover, we propose some potential new absorber materials using the SLME parameter.

In Section III, we present the methodology used. Section IV presents our results together with a discussion. We end this work with Section V, where we summarize our main findings.

\section{STRUCTURE OF THE CHALCOGENIDES MATERIALS}

The distribution of the cations within the unit cell of $\mathrm{Cu}_{2}-$ II-IV-VI ${ }_{4}$ depends on the nature of the group II and IV atoms. For example, the kesterite structure is the most stable phase for $\mathrm{Cu}_{2} \mathrm{ZnSnSe}_{4},{ }^{18}$ while it is reported that $\mathrm{Cu}_{2} \mathrm{CdSnSe}_{4}$ and $\mathrm{Cu}_{2} \mathrm{HgSnSe}_{4}$ prefer the stannite structure as the energetically favorable one. ${ }^{19,20}$ Because of the limited number of studies on the stannite structure of the quaternary $\mathrm{Cu}$-based chalcogenides, the optoelectronic properties of the compounds are not well-known. We investigate a group of $\mathrm{Cu}$-based materials that can be found in the stannite structure: $\mathrm{Cu}_{2}-\mathrm{II}-\mathrm{IV}-\mathrm{VI}_{4}$ with $\mathrm{II}=\{\mathrm{Cd}, \mathrm{Hg}$, and $\mathrm{Zn}\}, \mathrm{IV}=\{\mathrm{Sn}$, and $\mathrm{Ge}\}$, and $\mathrm{VI}=\{\mathrm{S}, \mathrm{Se}$, and $\mathrm{Te}\}$.

Stannite $\mathrm{Cu}_{2}-\mathrm{II}-\mathrm{IV}-\mathrm{VI}_{4}$ compounds are quaternary complexes with a crystal structure similar to the zinc-blende structure of $\mathrm{ZnS}$ and the kesterite structure of $\mathrm{CuInS}_{2}$. The stannite primitive cell (space group Ia $\overline{4} 2 \mathrm{~m}$, No. 121 ) contains 8 atoms.

Figure 1 presents the stannite structure. There are alternating cation layers of mixed II and IV atoms, which are separated from each other by layers of $\mathrm{Cu}$ monovalent cations. Each anion is tetrahedrally coordinated by four cations. Two equivalent $\mathrm{Cu}$ atoms occupy the $4 \mathrm{~d}$ Wyckoff position (site symmetry S4), one II atom on $2 a$, one IV atom on $2 b$ (both II and IV with $\mathrm{D}_{2 d}$ symmetry), and four VI atoms on $8 \mathrm{i}$ position (site symmetry $\mathrm{C}_{s}$ ). In this structure, each anion has thereby three inequivalent bonds (VI-Met) with the cations $\mathrm{Met}=\{\mathrm{Cu}, \mathrm{Zn}$, and $\mathrm{Sn}\}$.

\section{COMPUTATIONAL METHOD}

Our ab initio computations are based on density functional theory (DFT), ${ }^{21,22}$ and are carried out using the VASP code. $^{23-26}$ We use projector augmented wave $(\mathrm{PAW})^{27,28}$ potentials to describe the electron-ion interaction. We use the generalized gradient approximation (GGA) to the exchangecorrelation potential, in the Perdew, Burke, and Ernzerhof (PBE) parametrization ${ }^{29}$ to perform all structural calculations. Electronic structure and optical properties are calculated using the HSE06 hybrid functional..$^{30}$ An energy cutoff of $350 \mathrm{eV}$ is used for the plane-wave basis set. For structural relaxation and total energy calculations the Brillouin zone was sampled using a $4 \times 4 \times 4$ Monkhorst-Pack (MP) grid. ${ }^{31}$ Atomic relaxations were made until residual forces on the atoms were less than $0.01 \mathrm{eV} / \AA$ and total energies were converged to within $1 \mathrm{meV}$.

In order to calculate the absorption spectra, the imaginary part of the dielectric function tensor $(\varepsilon(\omega))$ is obtained using the random phase approximation, as implemented in the VASP code. ${ }^{32}$ Although in principle the electron-hole interaction can modify the optical spectrum and thus the SLME results, excitonic effects are expected to be small

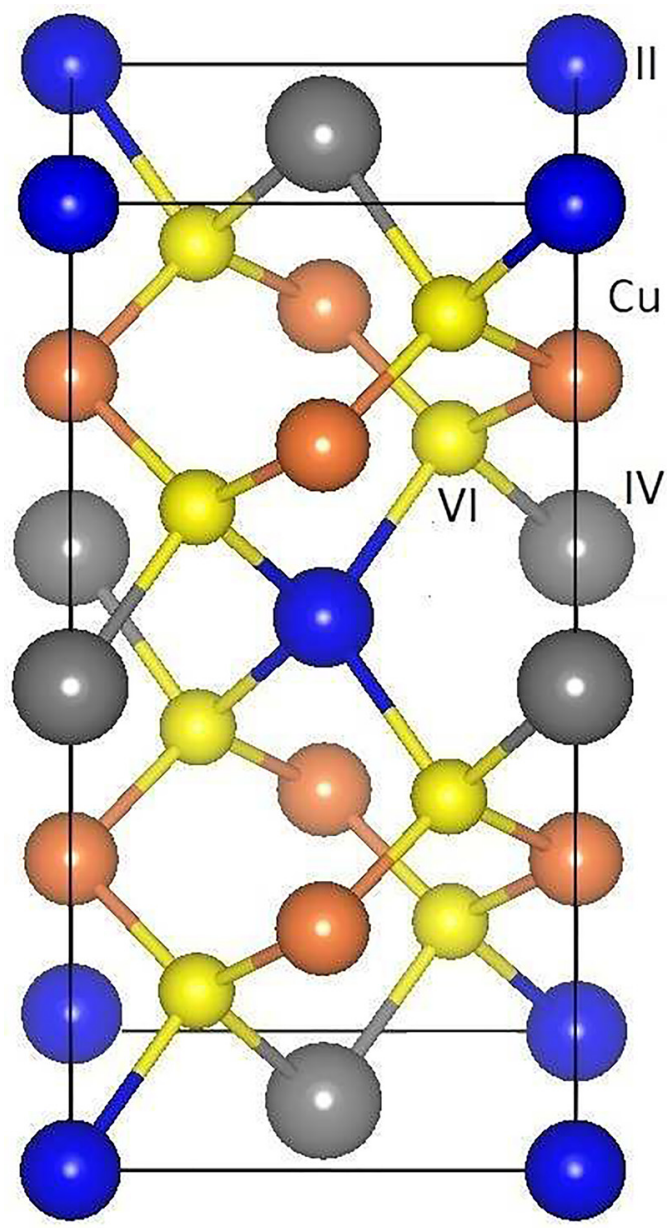

FIG. 1. Crystal structure of $\mathrm{Cu}_{2}-\mathrm{II}-\mathrm{IV}-\mathrm{VI}_{4}$-stannite (space group I $\overline{4} 2 \mathrm{~m}$, No. 121).

as shown for CZTS and CZTSe and are therefore not included. ${ }^{33}$ The dielectric function tensor of the studied compounds that have the tetragonal structure can be described completely by two non-zero independent components, namely, $\varepsilon^{\perp}=\varepsilon_{x x}=\varepsilon_{y y}$, and $\varepsilon^{\|}=\varepsilon_{z z}$ which corresponds to the dielectric function along the $\mathrm{x}$ - and $\mathrm{z}$-directions, respectively. The real part of the dielectric function is obtained from the imaginary part through the Kramers-Kronig relation. A Brillouin zone sampling using a $10 \times 10 \times 10 \mathrm{MP}$ grid is sufficient to obtain converged results for $\varepsilon(\omega)$. The number of unoccupied bands used here is 3 times the number of occupied bands.

Since the photovoltaic conversion efficiency strongly depends on the band gap, it is important to get an accurate value from our first-principles calculations. It is known that standard DFT calculations, using local or semi-local exchangecorrelation functionals such as the local density approximation (LDA) or GGA, seriously underestimate the band gap of semiconductors, ${ }^{30,34}$ while the hybrid functional HSE06 has proven to be capable of giving close-to-experiment predictions for a large range of compounds including Cu-based compounds. ${ }^{13,35}$ Moreover, for a series of compounds, HSE06 provides a dielectric function in much better agreement with experiment than GGA or LDA functionals. ${ }^{36,37}$

We calculate the power conversion efficiency $\eta$ of an absorber layer which is defined as $\eta=P_{m} / P_{i n}$, where $P_{m}$ is 
the maximum output power density and $P_{\text {in }}$ is the total incident solar power density. $P_{m}$ can be obtained by numerically maximizing $J \times V$ where $J$ is the current density and $V$ stands for voltage. The current density for a solar cell illuminated under the photon flux $I_{\text {sun }}$ is given by $J=J_{s c}-J_{\text {loss. }}{ }^{38} \mathrm{In}$ this work, the standard AM1.5G solar spectrum at $25^{\circ} \mathrm{C}$ is used. $^{39}$
The short-circuit current density $J_{s c}$ is given by

$$
J_{s c}=e \int_{0}^{\infty} a(E) I_{\text {sun }}(E) d E,
$$

where $e$ is the elementary charge and $a(E)$ is the photon absorptivity. The loss current density is calculated using the formula

TABLE I. HSE06 calculated lattice constants ( $a$ and $c$ in $\AA$ ), band gap $\left(E_{g}\right.$ in eV), enthalpy of formation $\left(\triangle H_{f}\right.$ in eV), ${ }^{\mathrm{a}}$ plasma frequency $\left(\omega_{p}^{a v r}\right.$. in eV), ${ }^{\mathrm{b}}$ and optical dielectric constant $\left(\varepsilon_{\infty}^{a v r}\right)^{\mathrm{b}}$ for the studied Cu-based chalcogenides. The calculated data are compared with other available results in the literature.

\begin{tabular}{|c|c|c|c|c|c|c|}
\hline Compound & $\mathrm{a}$ & $\mathrm{c} / \mathrm{a}$ & $\mathrm{E}_{g}$ & $\Delta \mathrm{H}_{f}$ & $\omega_{p}^{a v r}$ & $\varepsilon_{\infty}^{a v r} \cdot\left(\varepsilon_{\infty}^{\perp}, \varepsilon_{\infty}^{\|}\right)^{\mathrm{c}}$ \\
\hline \multirow[t]{2}{*}{$\mathrm{Cu}_{2} \mathrm{ZnGeS}_{4}$} & $\begin{array}{c}5.30 \\
5.34^{\mathrm{d}}(\text { Ref. 3) }\end{array}$ & $\begin{array}{c}2.02 \\
1.97^{\mathrm{d}}(\text { Ref. 3) }\end{array}$ & $\begin{array}{c}1.76 \\
2.04^{\mathrm{d}}(\text { Ref. } 41)\end{array}$ & -2.99 & 19.62 & $6.09(5.96,6.37)$ \\
\hline & $5.33^{\mathrm{e}}($ Ref. 41$)$ & $2.06^{\mathrm{e}}($ Ref. 41$)$ & $2.14^{\mathrm{f}}$ (Ref. 41) & & & $6.8^{\mathrm{e}}($ Ref. 41$)$ \\
\hline \multirow[t]{2}{*}{$\mathrm{Cu}_{2} \mathrm{ZnGeSe}_{4}$} & $\begin{array}{c}5.60 \\
5.63^{\mathrm{d}}(\text { Ref. } 42)\end{array}$ & $\begin{array}{c}2.01 \\
\left.1.96^{\mathrm{d}} \text { (Ref. } 42\right)\end{array}$ & $\begin{array}{c}0.90 \\
1.29^{\mathrm{d}} \text { (Ref. 41) }\end{array}$ & -2.31 & 18.16 & $7.56(7.36,7.97)$ \\
\hline & $5.38^{\mathrm{e}}($ Ref. 41$)$ & $2.02^{\mathrm{e}}$ (Ref. 41$)$ & $1.32^{\mathrm{f}}$ (Ref. 41) & & & $9.01^{\mathrm{e}}($ Ref. 41$)$ \\
\hline \multirow[t]{2}{*}{$\mathrm{Cu}_{2} \mathrm{ZnGeTe}_{4}$} & $\begin{array}{c}6.04 \\
5.60^{\mathrm{d}}(\text { Ref. } 3)\end{array}$ & $\begin{array}{c}1.99 \\
1.99^{\mathrm{d}}(\text { Ref. 3) }\end{array}$ & 0.49 & -3.21 & 16.53 & $10.17(9.89,10.73)$ \\
\hline & $6.09^{\mathrm{e}}($ Ref. 41$)$ & $2.00^{\mathrm{e}}$ (Ref. 41$)$ & $0.55^{\mathrm{f}}($ Ref. 41$)$ & & $17.93^{\mathrm{e}}($ Ref. 41$)$ & \\
\hline $\mathrm{Cu}_{2} \mathrm{ZnSnS}_{4}$ & $\begin{array}{c}5.42 \\
5.44^{\mathrm{d}}(\text { Ref. } 43) \\
5.34^{\mathrm{g}}(\text { Ref. } 44)\end{array}$ & $\begin{array}{c}2.01 \\
2.01^{\mathrm{d}}(\text { Ref. } 43) \\
2.01^{\mathrm{g}}(\text { Ref. } 44)\end{array}$ & $\begin{array}{c}1.30 \\
1.29^{\mathrm{d}} \text { (Ref. 43) } \\
1.27^{\mathrm{g}} \text { (Ref. 44) }\end{array}$ & -3.15 & 19.00 & $\begin{array}{c}6.25(6.12,6.53) \\
6.48^{\mathrm{d}}(\text { Ref. } 43) \\
6.99^{\mathrm{g}}(\mathrm{z})^{\mathrm{h}}(\text { Ref. } 44)\end{array}$ \\
\hline $\mathrm{Cu}_{2} \mathrm{ZnSnSe}_{4}$ & $\begin{array}{c}5.71 \\
5.61^{\mathrm{d}}(\text { Ref. 45) }\end{array}$ & $\begin{array}{c}2.00 \\
1.99^{\mathrm{d}} \text { (Ref. 45) }\end{array}$ & $\begin{array}{c}0.71 \\
1.41^{\mathrm{d}} \text { (Ref. 46) }\end{array}$ & -4.23 & 16.37 & $7.74(7.56,8.12)$ \\
\hline $\mathrm{Cu}_{2} \mathrm{ZnSnTe}_{4}$ & $\begin{array}{c}5.61^{\mathrm{s}}(\text { Ref. } 44) \\
6.13 \\
6.20^{\mathrm{d}}(\text { Ref. } 45) \\
6.20^{\mathrm{e}}(\text { Ref. } 45)\end{array}$ & $\begin{array}{c}1.99^{\mathrm{g}} \text { (Ref. 44) } \\
2.00 \\
1.99^{\mathrm{d}} \text { (Ref. 45) } \\
1.99^{\mathrm{e}} \text { (Ref. 45) }\end{array}$ & $\begin{array}{c}0.69^{\mathrm{g}} \text { (Ref. 44) } \\
0.58 \\
0.5^{\mathrm{d}}(\text { Ref. } 45)\end{array}$ & -2.24 & $\begin{array}{c}16.38 \\
14^{\mathrm{d}}(\text { Ref. } 45)\end{array}$ & $\begin{array}{c}8.19(\mathrm{x})^{\mathrm{h}}, 8.27^{\mathrm{g}}(\mathrm{z})^{\mathrm{h}}(\text { Ref. } 44) \\
9.74(9.53,10.17)\end{array}$ \\
\hline $\mathrm{Cu}_{2} \mathrm{CdGeS}_{4}$ & $\begin{array}{c}5.52 \\
5.34^{\mathrm{d}}(\text { Ref. } 47)\end{array}$ & $\begin{array}{c}1.91 \\
1.97^{\mathrm{d}} \text { (Ref. 47) }\end{array}$ & 1.71 & -3.97 & 19.02 & $6.06(6.24,7.88)$ \\
\hline $\mathrm{Cu}_{2} \mathrm{CdGeSe}_{4}$ & $\begin{array}{c}5.79 \\
5.75^{\mathrm{d}}(\text { Ref. } 48)\end{array}$ & $\begin{array}{c}1.92 \\
\left.1.92^{\mathrm{d}} \text { (Ref. } 48\right)\end{array}$ & $\begin{array}{c}0.95 \\
1.20^{\mathrm{d}}(\text { Ref. } 48)\end{array}$ & -3.08 & 18.46 & $7.51(7.33,7.88)$ \\
\hline $\mathrm{Cu}_{2} \mathrm{CdGeTe}_{4}$ & $\begin{array}{c}6.20 \\
6.13^{\mathrm{d}} \text { (Ref. 19) }\end{array}$ & $\begin{array}{c}1.93 \\
1.94^{\mathrm{d}}(\text { Ref. 19) }\end{array}$ & 0.71 & -2.24 & 16.36 & $9.78(9.50,10.33)$ \\
\hline $\mathrm{Cu}_{2} \mathrm{CdSnS}_{4}$ & $\begin{array}{c}5.62 \\
5.59^{\mathrm{d}}(\text { Ref. } 49)\end{array}$ & $\begin{array}{c}1.940 \\
1.94^{\mathrm{d}}(\text { Ref. } 49)\end{array}$ & $\begin{array}{c}1.22 \\
1.45^{\mathrm{d}} \text { (Ref. 50) }\end{array}$ & -3.74 & 18.68 & $6.25(6.10,6.56)$ \\
\hline $\mathrm{Cu}_{2} \mathrm{CdSnSe}_{4}$ & $\begin{array}{c}5.88 \\
5.81^{\mathrm{d}}(\text { Ref. } 51)\end{array}$ & $\begin{array}{c}1.95 \\
1.97^{\mathrm{d}}(\text { Ref. 51) }\end{array}$ & $\begin{array}{c}0.70 \\
0.96^{\mathrm{d}}(\text { Ref. } 52)\end{array}$ & -4.01 & 17.74 & $7.72(7.47,8.23)$ \\
\hline $\mathrm{Cu}_{2} \mathrm{CdSnTe}_{4}$ & $\begin{array}{c}6.27 \\
6.20^{\mathrm{d}} \text { (Ref. 53) }\end{array}$ & $\begin{array}{c}1.97 \\
1.98^{\mathrm{d}} \text { (Ref. 53) }\end{array}$ & 0.70 & -2.28 & 16.19 & $9.44(9.16,9.99)$ \\
\hline $\mathrm{Cu}_{2} \mathrm{HgGeS}_{4}$ & $\begin{array}{c}5.52 \\
5.49^{\mathrm{d}}(\text { Ref. } 54)\end{array}$ & $\begin{array}{c}1.92 \\
1.92^{\mathrm{d}} \text { (Ref. 54) }\end{array}$ & 1.21 & -3.05 & 19.43 & $6.79(6.75,6.87)$ \\
\hline $\mathrm{Cu}_{2} \mathrm{HgGeSe}_{4}$ & $\begin{array}{c}5.79 \\
5.69^{\mathrm{d}}(\text { Ref. } 51)\end{array}$ & $\begin{array}{c}1.92 \\
1.93^{\mathrm{d}}(\text { Ref. 51) }\end{array}$ & 0.54 & -3.14 & 18.40 & $8.90(8.74,9.23)$ \\
\hline $\mathrm{Cu}_{2} \mathrm{HgGeTe}_{4}$ & $\begin{array}{c}6.19 \\
6.11^{\mathrm{d}}(\text { Ref. 19) }\end{array}$ & $\begin{array}{c}1.94 \\
1.95^{\mathrm{d}}(\text { Ref. 19) }\end{array}$ & 0.38 & -1.74 & 17.06 & $11.93(11.81,12.18)$ \\
\hline $\mathrm{Cu}_{2} \mathrm{HgSnS}_{4}$ & $\begin{array}{c}5.61 \\
5.57^{\mathrm{d}}(\text { Ref. } 55)\end{array}$ & $\begin{array}{c}1.95 \\
1.95^{\mathrm{d}}(\text { Ref. 55) }\end{array}$ & 0.83 & -2.78 & 19.10 & $7.08(6.90,7.45)$ \\
\hline $\mathrm{Cu}_{2} \mathrm{HgSnSe}_{4}$ & $\begin{array}{c}5.88 \\
5.83^{\mathrm{d}}(\text { Ref. 19) } \\
5.84^{\mathrm{e}}(\text { Ref. 57) }\end{array}$ & $\begin{array}{c}1.95 \\
1.96^{\mathrm{d}}(\text { Ref. 19) } \\
1.97^{\mathrm{e}} \text { (Ref. 57) }\end{array}$ & $\begin{array}{c}0.36 \\
0.17^{\mathrm{d}}(\text { Ref. 56) }\end{array}$ & -2.28 & 18.12 & $\begin{array}{l}9.58(9.17,10.40) \\
\left.13.78^{\mathrm{e}} \text { (Ref. } 57\right)\end{array}$ \\
\hline $\mathrm{Cu}_{2} \mathrm{HgSnTe}_{4}$ & $\begin{array}{c}6.20 \\
6.19^{\mathrm{d}} \text { (Ref. 19) }\end{array}$ & $\begin{array}{c}1.97 \\
1.98^{\mathrm{d}}(\text { Ref. 19) }\end{array}$ & 0.39 & -1.71 & 16.15 & $11.38(11.21,11.70)$ \\
\hline
\end{tabular}

aThe GGA functional is used for the calculation of the enthalpy of formation.

${ }^{\mathrm{b}} \varepsilon_{\infty}^{a v r}$ and $\omega_{p}^{a v r}$. represent the value of an arithmetic average with respect to the direction of polarization.

${ }^{\mathrm{c}} \varepsilon_{\infty}^{\perp}$, and $\varepsilon_{\infty}^{\|}$are the optical dielectric constant along X-, and z-direction, respectively.

${ }^{\mathrm{d}}$ Experimental results.

e Theoretical results using GGA functional.

${ }^{\mathrm{f}}$ Theoretical results using GGA functional. A rigid shift is applied to correct the band gap. ${ }^{41}$

${ }^{\mathrm{g}}$ Theoretical results using HSE06 functional.

$\mathrm{h}(\mathrm{x})$, and $(\mathrm{z})$ refer to $\varepsilon_{\infty}$ in the $\mathrm{x}-$, and $\mathrm{z}$-direction, respectively. 


$$
J_{\text {loss }}=J_{0}\left(e^{e V / k_{B} T}-1\right),
$$

where $k_{B}$ is the Boltzmann constant, and $T$ the temperature. In this work all calculations are performed at $T=25^{\circ} \mathrm{C}$. $J_{0}=J_{0}^{n r}+J_{0}^{r} \equiv J_{0}^{r} / f_{r}$ corresponds to the total electron-hole recombination current density at equilibrium in the dark. This recombination includes both nonradiative $J_{0}^{n r}$ and radiative $J_{0}^{r}$ current densities, where $f_{r}$ is the fraction of the radiative recombination current. $f_{r}$ is approximated by $e^{-\Delta / k_{B} T}$ where $\Delta=E_{g}^{o p t}-E_{g} \cdot{ }^{13} E_{g}^{o p t}$ and $E_{g}$ are the optical and fundamental band gap, respectively. In equilibrium the rates of emission and absorption through cell surfaces should be equal in the dark. Thus, the rate of black-body photon absorption from the surrounding thermal bath through the front surface of the cell gives $J_{0}^{r}$

$$
J_{0}^{r}=e \pi \int_{0}^{\infty} a(E) I_{b b}(E, T) d E
$$

where $I_{b b}$ is the black-body spectrum. ${ }^{40}$ The absorptivity $\mathrm{a}(\mathrm{E})$ is modeled as $1-e^{2 \alpha(E) L}$, with $L$ the film thickness and $\alpha(E)$ the absorption spectrum of the material which is calculated from
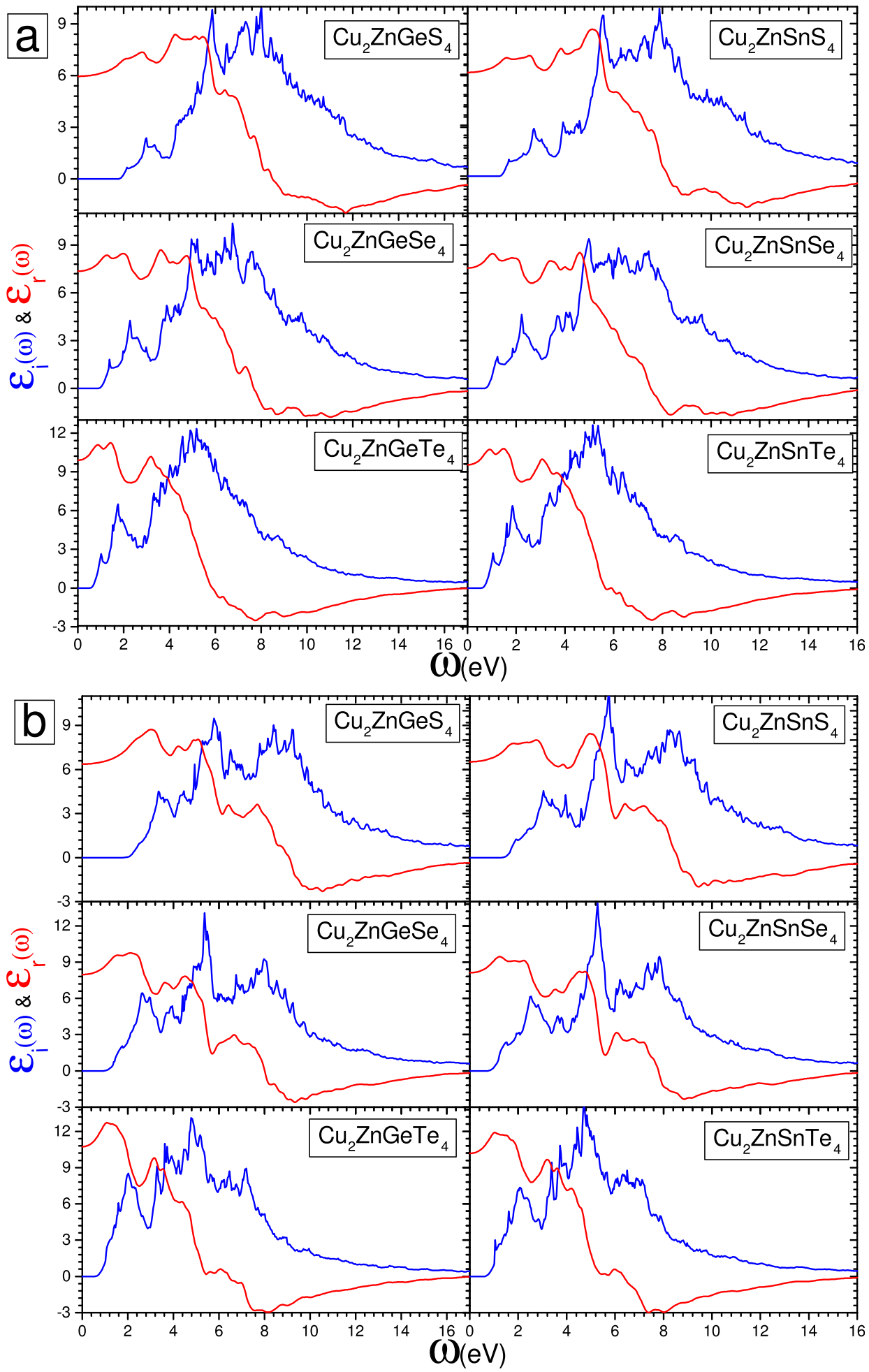

FIG. 2. Imaginary and real part of the dielectric function $\left(\varepsilon_{i}\right.$ and $\left.\varepsilon_{r}\right)$ along (a) the $\mathrm{x}$-direction and (b) the z-direction of the studied $\mathrm{Cu}_{2} \mathrm{Zn}$-based chalcogenides. For each compound, the blue and red figure correspond to $\varepsilon_{i}$ and $\varepsilon_{r}$, respectively. 


$$
\alpha(E)=\frac{2 \omega}{c} \sqrt{\frac{\sqrt{\varepsilon_{r}^{2}+\varepsilon_{i}^{2}}-\varepsilon_{r}}{2}},
$$

where $\mathrm{c}$ is the speed of light and $\varepsilon_{i}$ and $\varepsilon_{r}$ are the imaginary and real parts of the dielectric function, respectively. The factor 2 in the exponent accounts for the total reflectivity at the back surface of the absorber layer.

In addition to the power conversion efficiency we address the short-circuit current $J_{s c}$, the open-circuit voltage
$V_{o c}$ and the fill factor FF. The latter is a parameter that represents the maximum power from a solar cell and is defined by $F F=P_{m} / P_{\text {nom }}$ with the nominal power density $P_{\text {nom }}$ given by $J_{s c} \times V_{o c}$. The open circuit voltage $\left(V_{o c}\right)$ which is the voltage of the solar cell for $J=0$ is calculated using the formula

$$
V_{o c}=\frac{k_{B} T}{e} \ln \left(1+\frac{J_{s c}}{J_{0}}\right) .
$$
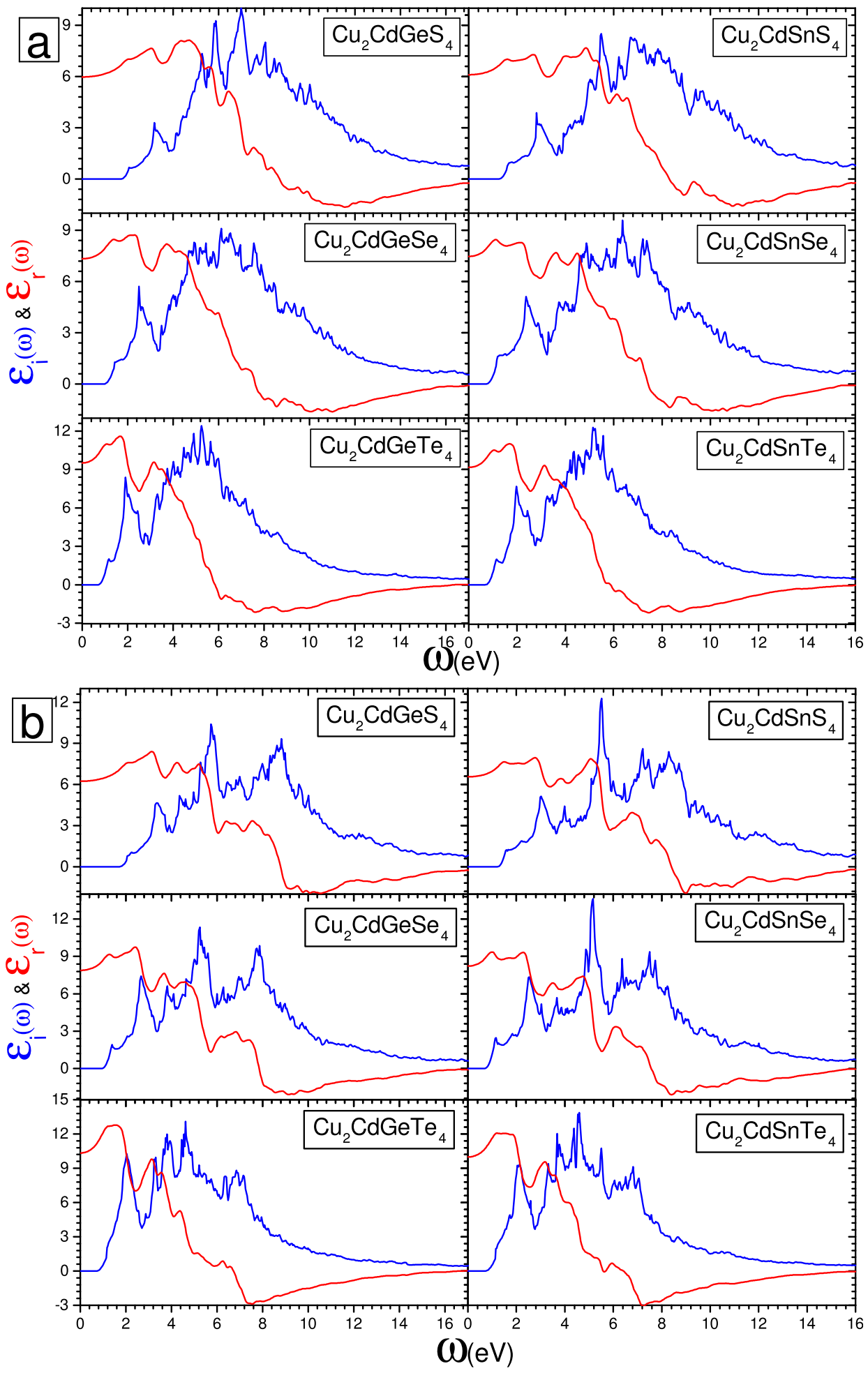

FIG. 3. Imaginary and real part of the dielectric function $\left(\varepsilon_{i}\right.$ and $\left.\varepsilon_{r}\right)$ along (a) the $\mathrm{x}$-direction and (b) the z-direction of the studied $\mathrm{Cu}_{2} \mathrm{Cd}$-based chalcogenides. For each compound, the blue and red figure correspond to $\varepsilon_{i}$ and $\varepsilon_{r}$, respectively. 


\section{RESULTS}

\section{A. Electronic structure and optical properties}

Table I presents the list of studied stannite $\mathrm{Cu}$-based chalcogenides in the following order: $\mathrm{Cu}_{2} \mathrm{Zn}$-based, $\mathrm{Cu}_{2} \mathrm{Cd}$ based, and then $\mathrm{Cu}_{2} \mathrm{Hg}$-based compounds. For each compound, the first row presents the calculated HSE06 results, and the following rows contain the available experimental and theoretical data. From Table I it is clear that the choice of the group VI element has a larger effect than that of the group II or IV element in altering the characteristics of the studied chalcogenides. Replacing a group VI element by one from the same group with a higher atomic number results in a red shift in the band gap. More effects of this replacement will be discussed in the following.

In order to calculate the current density, the absorptivity of the compound should be calculated (cf. Eqs. (1) and (3)). Using the dielectric function, the absorption spectra and absorptivity are calculated. Figures 2-4 show $\varepsilon_{i}$ and $\varepsilon_{r}$ for $\mathrm{Cu}$-based chalcogenides along the $\mathrm{x}$-, and $\mathrm{z}$-directions, $\varepsilon^{\perp}$, and $\varepsilon^{\|}$, respectively. We have noticed that the intensity of the peaks in $\varepsilon_{i}$ and the value of the optical dielectric constant
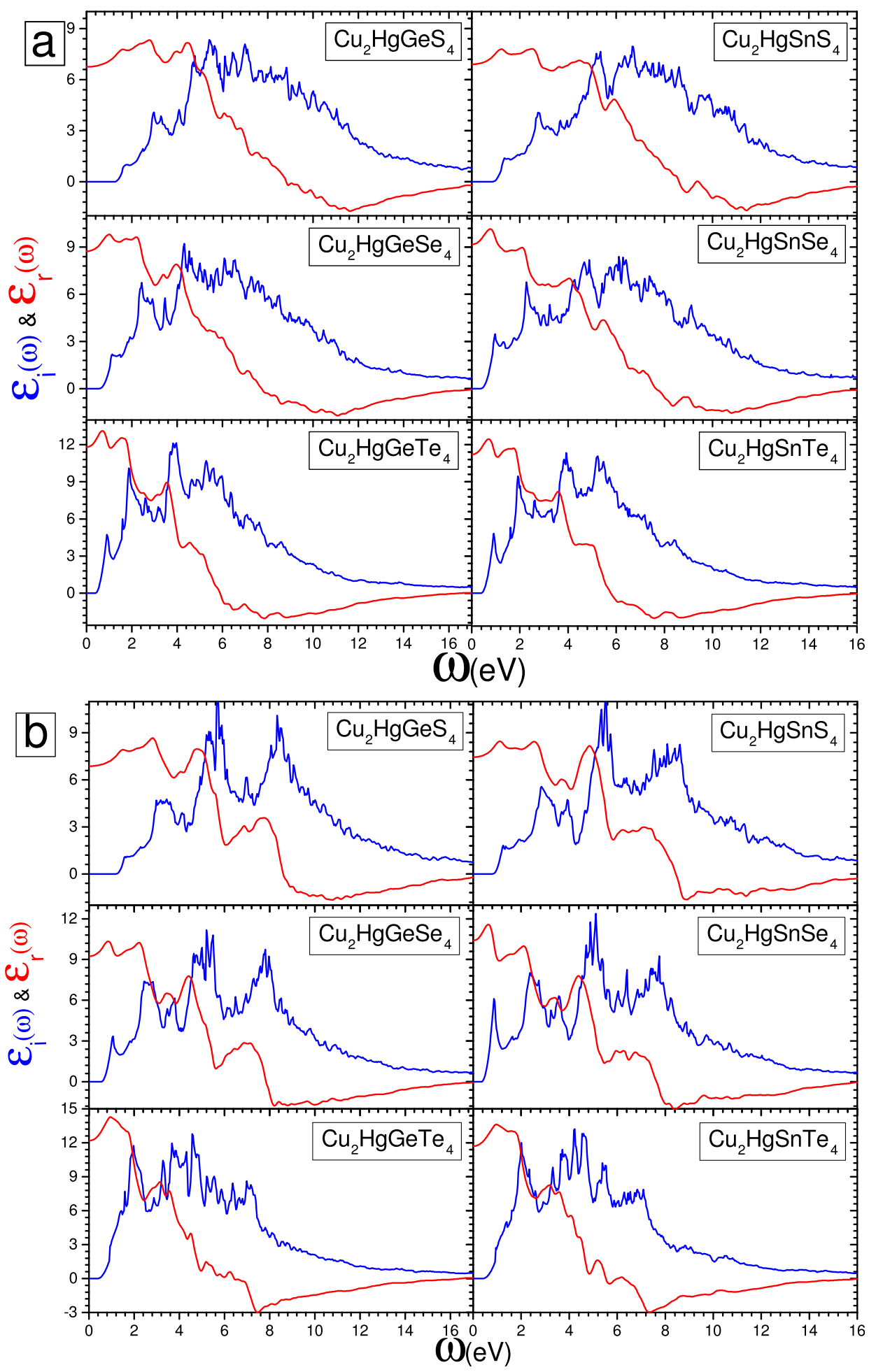

FIG. 4. Imaginary and real part of the dielectric function $\left(\varepsilon_{i}\right.$ and $\left.\varepsilon_{r}\right)$ along (a) the $\mathrm{x}$-direction and (b) the z-direction of the studied $\mathrm{Cu}_{2} \mathrm{Hg}$-based chalcogenides. For each compound, the blue and red figure correspond to $\varepsilon_{i}$ and $\varepsilon_{r}$, respectively. 
$\left(\varepsilon_{\infty}\right)$ along the z-direction are larger than those corresponding to the $\mathrm{x}$-direction. This results in a higher value of the refractive index along the z-direction compared with the one along the $\mathrm{x}$-direction, i.e., all studied compounds show positive birefringence $\left(\varepsilon_{\infty}^{\|}>\varepsilon_{\infty}^{\perp}\right)$.

Two aspects of the low frequency behavior of the dielectric function are relevant to experiment. One is the absorption edge, determined by onset of the imaginary part of the dielectric function and which provides the optical band gap. The other one is the zero frequency limit of the real part of the dielectric function, i.e., the optical dielectric constant $\varepsilon_{\infty}$ which is given in Table I. Table I shows that in each family of chalcogenides, e.g., $\mathrm{Cu}_{2} \mathrm{HgGe}-\mathrm{VI}_{4}$, by replacing the group VI element by one from the same group and with higher atomic number, there is an increase in $\varepsilon_{\infty}$. Such an increase in $\varepsilon_{\infty}$ indicates that the polarizability of the system tends to increase because of increasing ionicity of the bonds. Replacing S with Se and then by Te (i.e., increasing the ionic radius) results in a more extended electron cloud that screens the electric field more effectively and yields a higher polarizability. One can see from Table I that the plasma frequency $\left(\omega_{p}\right)$ decreases with the same substitution. Given that the number of valence electrons is the same for all of the studied chalcogenides, the decrease of $\omega_{p}$ can be understood as a consequence of the increased lattice constant on replacing an atom by a larger one.

The energy of the first direct allowed transition (optical band gap) can be found from the absorption spectra. In Figs. 5(a)-5(c) we present the arithmetic average of the absorption spectra. By replacing the group VI element by an element from the same group with a higher atomic number there is a red shift in the absorption edge and the band gap also shows the same trend. Moreover, from comparing the electronic band structure with the absorption spectrum we see that the first transition is direct and allowed. The electronic band structure of four typical chalcogenides is shown in Figs. 6(a)-6(d). The band gap value of all studied compounds is presented in Table I.

It is important that an absorber layer highly absorbs most part of the solar spectrum and in particular, the visible light. Substituting $\mathrm{S}$ by $\mathrm{Se}$ and then by Te (group VI element) increases the maximum absorption of the $\mathrm{Cu}_{2}-\mathrm{II}-\mathrm{IV}-\mathrm{VI}_{4}$ compounds in the visible range $(1.65-3.23 \mathrm{eV})$. For example, the maximum absorption of $\mathrm{Cu}_{2} \mathrm{HgGeS}_{4}, \mathrm{Cu}_{2} \mathrm{HgGeSe}_{4}$, and $\mathrm{Cu}_{2} \mathrm{HgGeTe}_{4}$ is $2.21,2.40$, and $4.17 \times 10^{-5} \mathrm{~cm}^{-1}$, respectively. The opposite trend is found for the optical band gap: $1.21 \mathrm{eV}\left(\mathrm{Cu}_{2} \mathrm{HgGeS}_{4}\right), 0.54 \mathrm{eV}\left(\mathrm{Cu}_{2} \mathrm{HgGeSe}_{4}\right)$, and $0.38 \mathrm{eV}$ $\left(\mathrm{Cu}_{2} \mathrm{HgGeTe}_{4}\right)$.

\section{B. Power conversion efficiency}

In order to calculate the SLME from the maximum output power of the absorber layer, we first plot the currentvoltage $(J-V)$ and power-voltage $(P-V)$ curve for the chalcogenides. Fig. 7 gives $J-V$ and $P-V$ curves for the chalcogenides with an SLME higher than $25 \%$. The same plot is shown for two common thin-film solar cell materials, $\mathrm{CuGaS}_{2}$ and $\mathrm{CuGaSe}_{2}$. Figure 8 gives $J-V$ and $P-V$ plots for the other studied compounds. The voltage is the difference
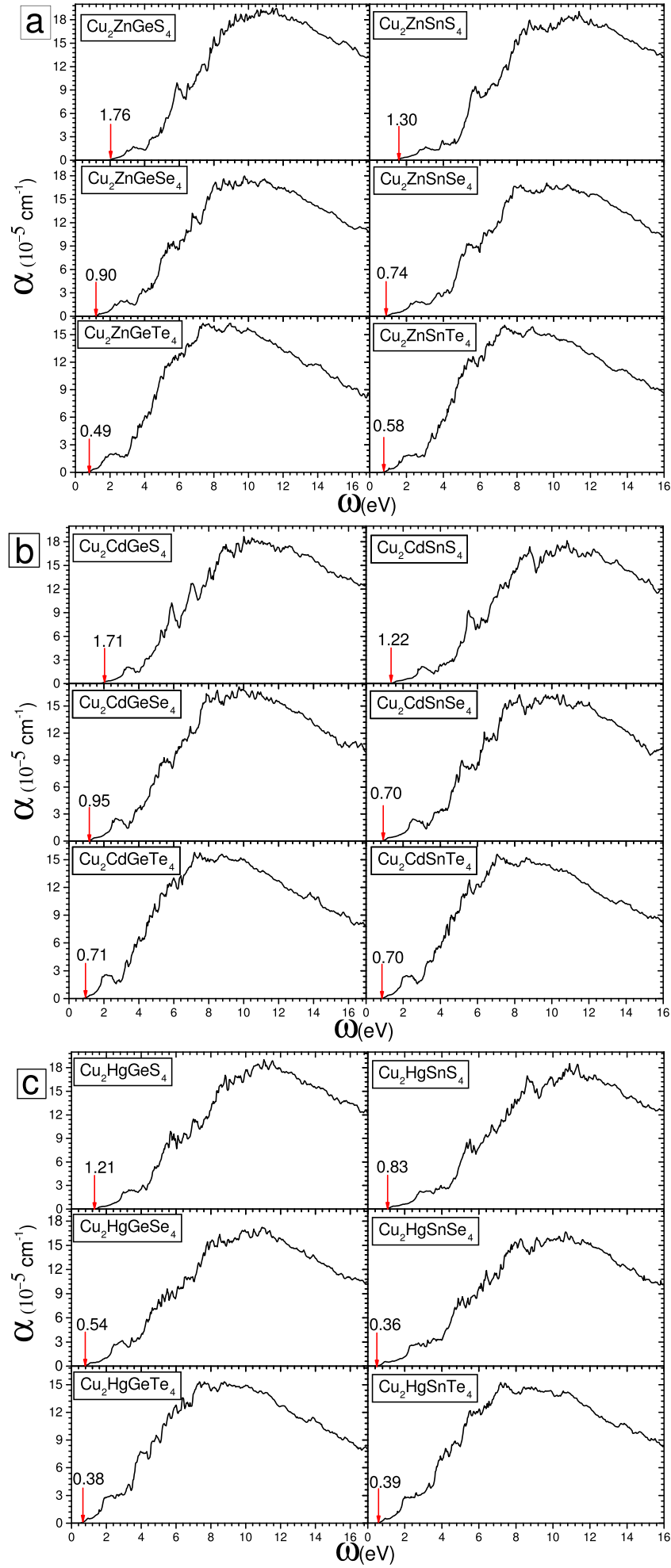

FIG. 5. Averaged absorption coefficient versus photon energy $(\mathrm{eV})$ for the studied (a) $\mathrm{Cu}_{2} \mathrm{Zn}$-based, (b) $\mathrm{Cu}_{2} \mathrm{Cd}$-based, and (c) $\mathrm{Cu}_{2} \mathrm{Hg}$-based chalcogenides. The value of the first direct allowed transition is given for each compound in the corresponding plot.

between the quasi Fermi level for electrons and holes. In the present case it arises from the incident photons on the solar cell. The voltage varies between zero and its maximum value $E_{g} / e$.

Figure 7 gives the voltage that maximizes the power density $\left(V_{m}\right)$ and $V_{o c}$. For each compound, the lower voltage 

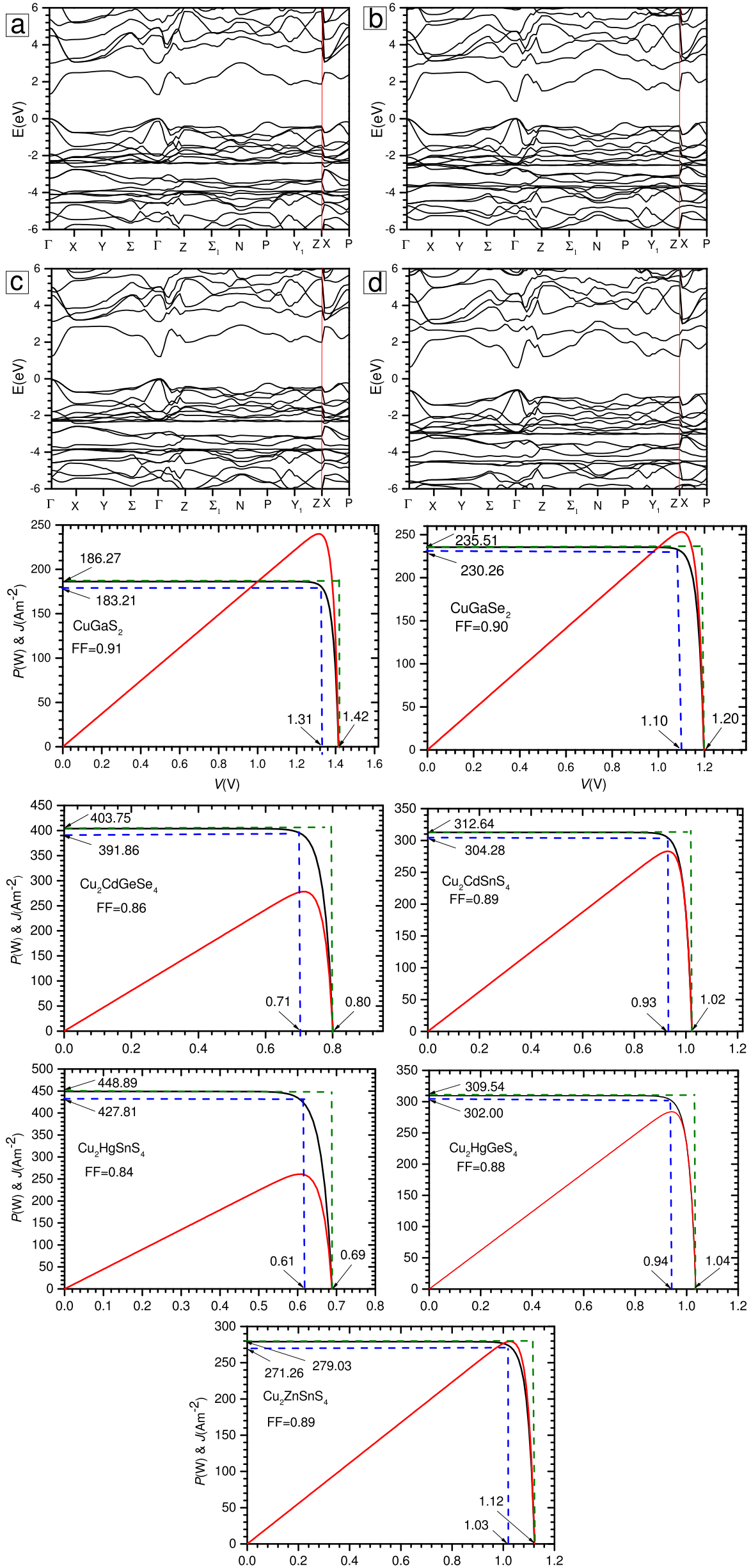

FIG. 6. Band structure for (a) $\mathrm{Cu}_{2} \mathrm{Zn}$ $\mathrm{SnS}_{4}$, (b) $\mathrm{Cu}_{2} \mathrm{CdGeSe}_{4}$, (c) $\mathrm{Cu}_{2} \mathrm{CdSnS}_{4}$, and (d) $\mathrm{Cu}_{2} \mathrm{HgGeS}_{4}$.

FIG. 7. Current density (black curve) and power density (red curve) of the absorber layer (with a thickness of $0.5 \mu \mathrm{m}$ ) with respect to the voltage. Blue and green dashed lines represent the $P_{m}$ and, $P_{n o m}$, respectively. The lowest and highest values indicated along the voltage axis refer to $V_{m}$ and $V_{o c}$, respectively, whereas along the current density axis they refer to $J_{m}$ and $J_{s c}$, respectively. 

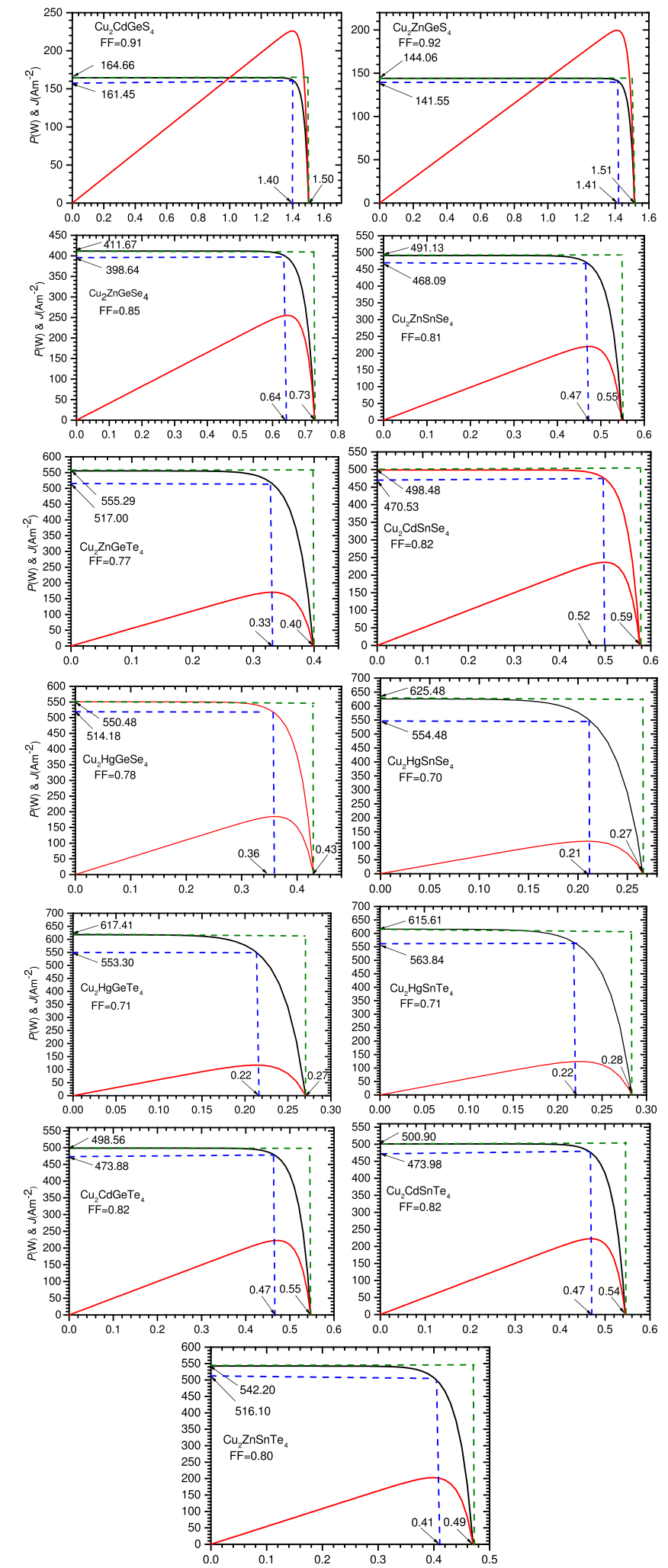

FIG. 8. Current density (black curve) and power density (red curve) of the absorber layer (with a thickness of $0.5 \mu \mathrm{m}$ ) with respect to the voltage. Blue and green dashed lines represent the $P_{m}$ and $P_{n o m}$, respectively. The lowest and highest values indicated along the voltage axis refer to $V_{m}$ and $V_{o c}$, respectively, whereas along the current density axis they refer to $J_{m}$ and $J_{s c}$, respectively.

is $V_{m}$, and the higher one corresponds to $V_{o c} . P_{m}$ and $P_{\text {nom }}$ are presented in Fig. 7 by blue and green dashed lines, respectively. Each plot gives two more values, namely, the current density that maximizes the power density $J_{m}$ (lower one) and $J_{s c}$ (higher one). According to the definition of $J_{s c}$ and $J_{m}, J_{s c}$ is always larger than $J_{m}$ and this difference depends on the recombination rate. It can be shown that Eq. 5 implies that $V_{o c}$ is always larger than $V_{m}$. Altogether, $P_{\text {nom }}$ is always larger by a factor (FF) than $P_{m}$. The FF values are given for each compound in the corresponding plot in Fig. 7. 
TABLE II. The voltage that maximizes the power density $\left(V_{m}\right.$ in V), the current density that maximizes the power density $\left(J_{m}\right.$ in $\left.\mathrm{Am}^{-2}\right)$, open circuit voltage $\left(V_{o c}\right.$ in $\left.\mathrm{V}\right)$, short circuit current density $\left(J_{s c}\right.$ in $\left.\mathrm{Am}^{-2}\right)$, fill factor (FF), SLME (\%), and SQ limit (\%) for the studied Cu-based chalcogenides.

\begin{tabular}{lccccccc}
\hline \hline Compound & $V_{m}$ & $J_{m}$ & $V_{o c}$ & $J_{s c}$ & FF & SLME (\%) & SQ \\
\hline $\mathrm{Cu}_{2} \mathrm{ZnGeS}_{4}$ & 1.41 & 141.55 & 1.51 & 144.06 & 0.92 & 19.96 & 27.96 \\
$\mathrm{Cu}_{2} \mathrm{ZnGeSe}_{4}$ & 0.64 & 398.64 & 0.73 & 411.67 & 0.85 & 25.51 & 29.48 \\
$\mathrm{Cu}_{2} \mathrm{ZnGeTe}_{4}$ & 0.33 & 517.00 & 0.40 & 555.29 & 0.77 & 17.06 & 16.77 \\
$\mathrm{Cu}_{2} \mathrm{ZnSnS}_{4}$ & 1.03 & 271.26 & 1.12 & 279.03 & 0.89 & 27.94 & 33.16 \\
$\mathrm{Cu}_{2} \mathrm{ZnSnSe}_{4}$ & 0.47 & 468.09 & 0.55 & 491.13 & 0.81 & 22.00 & 24.06 \\
$\mathrm{Cu}_{2} \mathrm{ZnSnTe}_{4}$ & 0.41 & 516.10 & 0.49 & 542.20 & 0.80 & 21.16 & 18.66 \\
$\mathrm{Cu}_{2} \mathrm{CdGeS}_{4}$ & 1.40 & 161.45 & 1.50 & 164.66 & 0.91 & 22.82 & 28.86 \\
$\mathrm{Cu}_{2} \mathrm{CdGeSe}_{4}$ & 0.71 & 391.86 & 0.80 & 403.75 & 0.86 & 28.50 & 31.14 \\
$\mathrm{Cu}_{2} \mathrm{CdGeTe}_{4}$ & 0.47 & 473.88 & 0.55 & 498.56 & 0.82 & 22.27 & 24.06 \\
$\mathrm{Cu}_{2} \mathrm{CdSnS}_{4}$ & 0.93 & 304.28 & 1.02 & 312.64 & 0.89 & 28.30 & 33.29 \\
$\mathrm{Cu}_{2} \mathrm{CdSnSe}_{4}$ & 0.52 & 470.53 & 0.59 & 498.48 & 0.83 & 24.47 & 23.76 \\
$\mathrm{Cu}_{2} \mathrm{CdSnTe}_{4}$ & 0.47 & 473.98 & 0.54 & 500.90 & 0.82 & 22.28 & 23.76 \\
$\mathrm{Cu}_{2} \mathrm{HgGeS}_{4}$ & 0.94 & 302.01 & 1.04 & 309.54 & 0.88 & 28.39 & 33.35 \\
$\mathrm{Cu}_{2} \mathrm{HgGeSe}_{4}$ & 0.36 & 514.18 & 0.43 & 550.48 & 0.78 & 18.51 & 16.77 \\
$\mathrm{Cu}_{2} \mathrm{HgGeTe}_{4}$ & 0.22 & 553.30 & 0.27 & 617.41 & 0.71 & 12.72 & 8.72 \\
$\mathrm{Cu}_{2} \mathrm{HgSnS}_{4}$ & 0.61 & 427.81 & 0.69 & 448.89 & 0.84 & 26.10 & 26.55 \\
$\mathrm{Cu}_{2} \mathrm{HgSnSe}_{4}$ & 0.21 & 554.48 & 0.27 & 625.48 & 0.70 & 11.64 & 7.77 \\
$\mathrm{Cu}_{2} \mathrm{HgSnTe}_{4}$ & 0.22 & 563.84 & 0.28 & 615.61 & 0.71 & 12.40 & 9.22 \\
\hline \hline
\end{tabular}

The FF values, together with $V_{o c}, V_{m}, J_{s c}$, and $V_{m}$ are given in Table II. The SLME value and the corresponding SQ limit are also given in the same table. Table II shows a large $J_{s c}$ of $411.67 \mathrm{Am}^{-2}$ for $\mathrm{Cu}_{2} \mathrm{ZnGeSe}_{4}$. However, this compound has a rather small $V_{o c}$ compared with that of some of the other compounds, which finally results in a low output power, $\mathrm{FF}$, and efficiency. On the other hand, $\mathrm{Cu}_{2} \mathrm{CdGeS}_{4}$ with low $J_{s c}$ has a large $V_{o c}$ and therefore yields a large efficiency and FF.

The decrease of efficiency with the reduction of layer thickness puts a lower bound on that thickness. For very large thicknesses the SLME converges to the corresponding SQ limit. But the rate of convergence depends on the details of the absorption spectrum and identifying materials with a fast convergence towards the SQ limit is highly desirable.

Figure 9 represents the SLME as a function of film thickness for four studied chalcogenides. For the SLME calculation we consider a layer thickness $L=0.5 \mu \mathrm{m}$ because beyond that value the efficiency hardly changes whereas below that value a considerable loss of efficiency is observed on reducing the layer thickness as shown in Fig. 9.

Figure 10 presents the SLME parameter for the studied compounds as a function of the band gap energy. The calculated SLME value for two well-known absorber layer materials $\left(\mathrm{CuGaS}_{2}\right.$ and $\left.\mathrm{CuGaSe}_{2}\right)$ is also represented. The SQ limit is also shown.

One can see from Fig. 10 that the SLME value of some of the considered compounds is higher than the corresponding SQ limit, which is considered as a theoretical upper limit for the efficiency of the absorber layer. However, in a separate publication we show that this is not necessarily the case. $^{58}$ As shown by $\mathrm{Yu}$ and Zunger ${ }^{13}$ the SLME is more powerful than the SQ limit in ranking the compounds based on their power conversion efficiency by including the optical

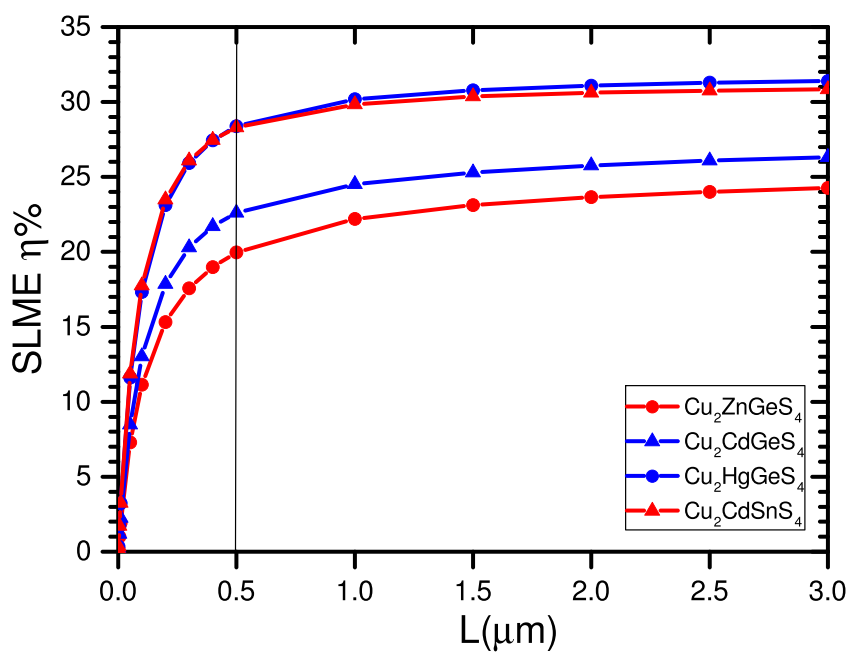

FIG. 9. The SLME as a function of film thickness for $\mathrm{Cu}_{2} \mathrm{CdGeS}_{4}$, $\mathrm{Cu}_{2} \mathrm{ZnGeS}_{4}, \mathrm{Cu}_{2} \mathrm{HgGeS}_{4}$, and $\mathrm{Cu}_{2} \mathrm{CdSnS}_{4}$. The vertical line indicates the thickness used in Fig. 10.

properties of the materials. For example a comparison between $\mathrm{Cu}_{2} \mathrm{CdGeSe}_{4}$ and $\mathrm{Cu}_{2} \mathrm{ZnSnS}_{4}$ shows that it is possible to have a high efficiency absorber layer with a nonoptimum band gap material. $\mathrm{Cu}_{2} \mathrm{CdGeSe}_{4}$ has a band gap of $0.95 \mathrm{eV}$ and the band gap of $\mathrm{Cu}_{2} \mathrm{ZnSnS}_{4}$ is $1.30 \mathrm{eV}$. According to the SQ limit, the latter is expected to have a higher efficiency. However, the former compound has a higher absorption and therefore results in a higher efficiency.

Based on Fig. 10 our calculations identify five quaternary Cu-based chalcogenides, namely, $\mathrm{Cu}_{2} \mathrm{CdGeSe}_{4}, \mathrm{Cu}_{2} \mathrm{CdSnS}_{4}$, $\mathrm{Cu}_{2} \mathrm{HgGeS}_{4}, \mathrm{Cu}_{2} \mathrm{HgSnS}_{4}$, and $\mathrm{Cu}_{2} \mathrm{ZnSnS}_{4}$, as possible absorber layers with a power efficiency higher than $25 \%$. Their theoretical efficiency stays considerably above that of the other studied chalcogenides. The latter material (CZTS) with a calculated SLME of $28.40 \%$ is already used as an absorber layer in photovoltaic cells. The measured cell efficiency for CZTS is $12.6 \%$ lower than its SLME value ${ }^{59}$ because of (i) the difference between solar cell and absorber

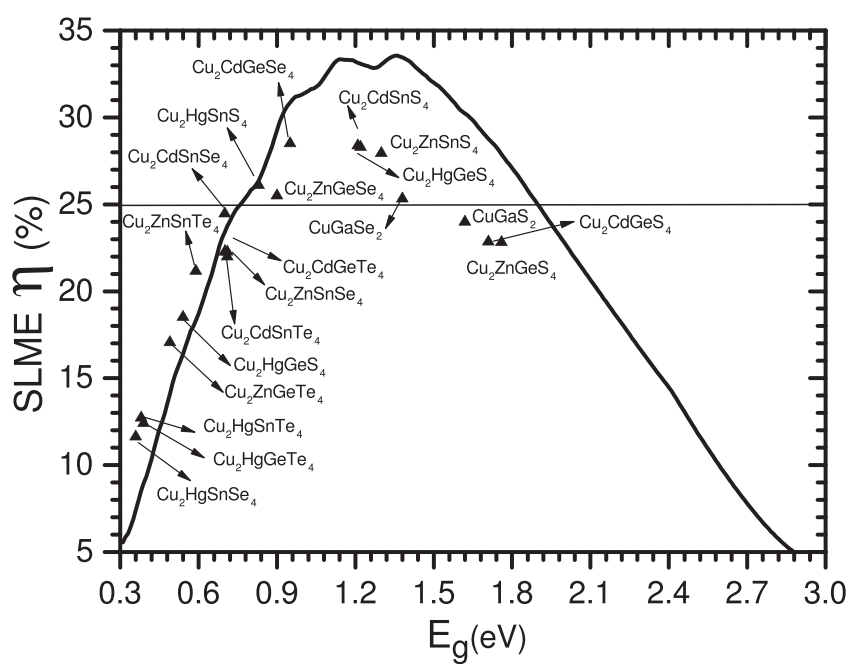

FIG. 10. SLME versus the band gap $\left(\mathrm{E}_{g}\right)$ for the studied chalcogenides at $L=0.5 \mu \mathrm{m}$. The full line presents the SQ limit. 
layer and (ii) the presence of electron-hole recombination centers. The latter should be prohibited to get the maximum theoretical power conversion efficiency. Further studies on the formation of native defects in the identified compounds are required to understand better the power conversion efficiency limit applied to these materials.

For comparison we also calculate the band structure and optical properties for $\mathrm{CuGaS}_{2}$, and $\mathrm{CuGaSe}_{2}$ with the chalcopyrite structure. The HSE06 calculations for the band gap result in 1.62 and $1.38 \mathrm{eV}$ for $\mathrm{CuGaS}_{2}$ and $\mathrm{CuGaSe}_{2}$, respectively, which is an underestimation of $33 \%$ and $17 \%$ with respect to the experimental value. ${ }^{6}$ We calculate $24 \%$ and $25.33 \%$ for the SLME of the considered compounds. A comparison between our results with existing results that used the GW approximation for the band gap calculation ${ }^{13}$ and HSE06 for the optical properties shows $7.5 \%$ and $1.3 \%$ difference in the SLME value for these compounds. However, both calculations result in a higher band gap and a higher SLME for $\mathrm{CuGaSe}_{2}$.

\section{CONCLUSION}

The results of the present work show that the optoelectronic properties of the studied $\mathrm{Cu}$-based chalcogenides $\mathrm{Cu}_{2}-$ II-IV-VI ${ }_{4}$ strongly depend on the group VI element in the composition of the material. The change of the group VI element has a higher effect than changing the group II or IV element in altering the characteristics of the studied chalcogenides. Replacement of the group VI element by one from the same group with a higher atomic number decreases the plasma frequency and band gap and at the same time results in an increase of the lattice parameters, and optical dielectric constant. A clear red shift in the absorption edge is observed which is correlated with the decrease in the band gap. Further studies of the compounds of interest show that besides the fundamental band gap, the absorption coefficient plays an important role in the efficiency of the absorber layer. In particular for materials with the same band gap a higher absorption leads to a higher efficiency. Finally, the results of the calculations identify $\mathrm{Cu}_{2} \mathrm{II}-\mathrm{GeSe}_{4}$ with $\mathrm{II}=\mathrm{Cd}$, and $\mathrm{Hg}$ and $\mathrm{Cu}_{2}-\mathrm{II}-\mathrm{SnS}_{4}$ with $\mathrm{II}=\mathrm{Cd}, \mathrm{Hg}$, and $\mathrm{Zn}$ as high efficiency absorber layers.

\section{ACKNOWLEDGMENTS}

We acknowledge the financial support from the FWOVlaanderen through project G.0150.13N and a GOA fund from the University of Antwerp. The computational resources and services used in this work were provided by the VSC (Flemish Supercomputer Center) and the HPC infrastructure of the University of Antwerp (CalcUA), both funded by the FWO-Vlaanderen and the Flemish Government-department EWI.

${ }^{1}$ H. Katagiri, K. Jimbo, S. Yamada, T. Kamimura, W. S. Maw, T. Fukano, T. Ito, and T. Motohiro, Appl. Phys. Express 1, 041201 (2008).

${ }^{2}$ S. Schorr, G. Wagner, M. Tovar, and D. Sheptyakov, in Structure and Microstructure of $\mathrm{Zn}_{2 x}\left(\mathrm{CuB}{ }^{I I I}\right)_{1-x} X_{2} \quad$ Semiconductors $\quad\left(B^{I I I}=G a\right.$,In; $X=S, S e, T e$ ) (Mater. Res. Soc. Symp. Proc., 2007), Vol. 1012, p. Y03.

${ }^{3}$ O. V. Parasyuk, I. D. Olekseyuk, and L. V. Piskach, J. Alloys Compd. 397, 169 (2005).
${ }^{4}$ H. Matsushita, T. Maeda, A. Katsui, and T. Takizawa, J. Cryst. Growth 208, 416 (2000).

${ }^{5}$ S. Chen, X. G. Gong, A. Walsh, and S. H. Wei, Appl. Phys. Lett. 94, 041903 (2009).

${ }^{6}$ O. M. Madelung, Semiconductors: Data Handbook, 3rd ed. (Springer, New York, 2004).

${ }^{7}$ O. V. Parasyuk, L. D. Gulay, Y. E. Romanyuk, and L. V. Piskach, J. Alloys Compd. 329, 202 (2001).

${ }^{8}$ T. K. Todorov, J. Tang, S. Bag, O. Gunawan, T. Gokmen, Y. Zhu, and D. B. Mitzi, Adv. Energy Mater. 3, 34 (2013).

${ }^{9}$ D. Barkhouse, O. Gunawan, T. Gokmen, T. Todorov, and D. Mitzi, Prog. Photovoltaics 20, 6 (2012).

${ }^{10}$ J. J. Scragg, P. J. Dale, and L. M. Peter, Electrochem. Commun. 10, 639 (2008).

${ }^{11}$ M. Altosaar, J. Raudoja, K. Timmo, M. Danilson, M. Grossberg, J. Krustok, and E. Mellikov, Phys. Status Solidi A 205, 167 (2008).

${ }^{12}$ S. Siebentritt, Thin Solid Films 535, 1 (2013).

${ }^{13}$ L. Yu and A. Zunger, Phys. Rev. Lett. 108, 068701 (2012).

${ }^{14}$ W. J. Yin, T. Shi, and Y. Yan, Adv. Mater. 26, 4653 (2014).

${ }^{15}$ I. H. Lee, J. Lee, Y. J. Oh, S. Kim, and K. J. Chang, Phys. Rev. B 90, 115209 (2014).

${ }^{16}$ W. Shockley and H. J. Queisser, J. Appl. Phys. 32, 510 (1961).

${ }^{17}$ T. Jäger, Y. E. Romanyuk, B. Bissig, F. Pianezzi, S. Nishiwaki, P. Reinhard, J. Steinhauser, J. Schwenk, and A. N. Tiwari, J. Appl. Phys. 117, 225303 (2015)

${ }^{18}$ S. Schorr, Sol. Energy Mater. Sol. Cells 95, 1482 (2011).

${ }^{19}$ I. D. Olekseyuk, L. D. Gulay, I. V. Dydchak, L. V. Piskach, O. V. Parasyuk, and O. V. Marchuk, J. Alloys Compd. 340, 141 (2002).

${ }^{20}$ M. L. Liu, I. W. Chen, F. Q. Huang, and L. D. Chen, Adv. Mater. 21, 3808 (2009).

${ }^{21}$ P. Hohenberg and W. Kohn, Phys. Rev. 136, B864 (1964).

${ }^{22}$ W. Kohn and L. J. Sham, Phys. Rev. 140, A1133 (1965).

${ }^{23}$ G. Kresse and J. Hafner, Phys. Rev. B 47, R558 (1993).

${ }^{24}$ G. Kresse and J. Hafner, J. Phys.: Condens. Matter 6, 8245 (1994).

${ }^{25}$ G. Kresse and J. Furthmüller, Comput. Mater. Sci. 6, 15 (1996).

${ }^{26}$ G. Kresse and J. Furthmüller, Phys. Rev. B 54, 11169 (1996).

${ }^{27}$ G. Kresse and D. Joubert, Phys. Rev. B 59, 1758 (1999).

${ }^{28}$ P. E. Blöchl, Phys. Rev. B 50, 17953 (1994).

${ }^{29}$ J. P. Perdew, K. Burke, and M. Ernzerhof, Phys. Rev. Lett. 77, 3865 (1996).

${ }^{30}$ C. S. Wang and W. E. Pickett, Phys. Rev. Lett. 51, 597 (1983).

${ }^{31}$ H. J. Monkhorst and J. D. Pack, Phys. Rev. B 13, 5188 (1976).

${ }^{32}$ M. Gajdos, K. Hummer, G. Kresse, J. Furthmüller, and F. Bechstedt, Phys. Rev. B 73, 045112 (2006).

${ }^{33}$ S. Körbel, D. Kammerlander, R. Sarmiento-Pérez, C. Attaccalite, M. A. L. Marques, and S. Botti, Phys. Rev. B 91, 075134 (2015).

${ }^{34}$ K. A. Johnson and N. W. Ashcroft, Phys. Rev. B 58, 15548 (1998).

${ }^{35}$ T. M. Henderson, J. Paier, and G. E. Scuseria, Phys. Status Solidi B 248, 767 (2011).

${ }^{36}$ F. L. Tang, Z. X. Zhu, H. T. Xue, W. J. Lu, Y. D. Feng, Z. M. Wang, and Y. Wang, Physica B 407, 4814 (2012).

${ }^{37}$ F. C. Wan, F. L. Tang, Z. X. Zhu, H. T. Xue, W. J. Lu, Y. D. Feng, and Z. Y. Rui, Mater. Sci. Semicond. Process. 16, 1422 (2013).

${ }^{38}$ M. A. Green, Third Generation Photovoltaics: Advanced Solar Energy Conversion (Springer, New York, 2003).

${ }^{39} \mathrm{See}$ http://rredc.nrel.gov/solar/spectra/am1.5/ for "Reference Solar Spectral Irradiance: Air Mass 1.5" (last accessed February 08, 2013).

${ }^{40}$ T. Tiedje, E. Yablonovitch, G. Cody, and B. Brooks, IEEE Trans. Electron Devices 31, 711 (1984).

${ }^{41}$ D. Chen and N. M. Ravindra, J. Alloys Compd. 579, 468 (2013).

${ }^{42}$ P. U. Bhaskar, G. S. Babu, Y. B. K. Kumar, and V. S. Raja, Thin Solid Films 534, 249 (2013).

${ }^{43}$ J. Paier, R. Asahi, A. Nagoya, and G. Kresse, Phys. Rev. B 79, 115126 (2009).

${ }^{44} \mathrm{H}$. Zhao and C. Persson, Thin Solid Films 519, 7508 (2011).

${ }^{45}$ H. Shen, X. D. Jiang, S. Wang, Y. Fu, C. Zhou, and L. S. Li, J. Mater. Chem. 22, 25050 (2012).

${ }^{46}$ M. L. Liu, F. Q. Huang, L. D. Chen, and I. Chen, Appl. Phys. Lett. 94, 202103 (2009).

${ }^{47}$ J. L. Jambor and A. C. Roberts, Am. Mineral. 84, 1464 (1999).

${ }^{48}$ L. V. Piskach, O. V. Parasyuk, and Y. E. Romanyuk, J. Alloys Compd. 299, 227 (2000).

${ }^{49}$ W. Schäfer and R. Nitsche, Z. Kristallogr. 145, 356 (1977).

${ }^{50}$ H. Guan, J. Zhao, X. Wang, and F. Yu, Chalcogenide Lett. 10, 367 (2013).

${ }^{51}$ H. Hahn and H. Schulze, Naturwissenschaften 52, 426 (1965). 
${ }^{52}$ M. Ibánez, D. Cadavid, R. Zamani, N. G. Castelló, V. I. Roca, W. Li, A. Fairbrother, J. D. Prades, A. Shavel, J. Arbiol, A. P. Rodríguez, J. R. Morante, and A. Cabot, Chem. Mater. 24, 562 (2012).

${ }^{53}$ H. Haeuseler, F. W. Ohrendorf, and M. Himmrich, Z. Naturforsch. B 46, 1049 (1991).

${ }^{54}$ W. Schäfer and R. Nitsche, Mater. Res. Bull. 9, 645 (1974).

${ }^{55}$ Y. K. Kabalov, T. L. Evstigneeva, and E. M. Spiridonov, Crystallography reports 43, 16 (1998).
${ }^{56}$ S. A. Mkrtchyan, K. O. Dovletov, E. G. Zhukov, A. G. Melikdzhanyan, and S. Nuriev, Neorg. Mater. 24, 1094 (1988).

${ }^{57}$ D. Li, X. Zhang, Z. Zhu, H. Zhang, and F. Ling, Solid State Sci. 14, 890 (2012).

${ }^{58}$ M. Bercx, N. Sarmadian, R. Saniz, B. Partoens, and D. Lamoen, Phys. Chem. Chem. Phys. 18, 20542-20549 (2016).

${ }^{59}$ W. Wang, M. T. Winkler, O. Gunawan, T. Gokmen, T. K. Todorov, Y. Zhu, and D. B. Mitzi, Adv. Energy Mater. 4, 1301465 (2014). 